\title{
Satan or Socrates: \\ The Perils of Excessive Pride in Pedagogy
}

\author{
Satán o Sócrates: \\ El Peligro de la Arrogancia Excesiva en la \\ Pedagogía
}

\section{Satan ou Socrate : \\ Les Périls de l'Orgueil Excessif en Pédagogie}

\section{Theodore Christou}

Queen's University

\section{Introduction}

$\mathrm{T}$

HIS ESSAY ARGUES that modesty in pedagogical practice is necessary. This term - modesty - is used to describe an orientation towards educational knowledge that sees pedagogues, in all contexts and arenas, as necessarily acknowledging their ignorance in regard to education. No matter the profundity of their educational experience, educators must approach each teaching situation humbly - as supplicants and as devotees might a sacred place; the acknowledgement of any knowledge is assumptive and presumptive.

This essay unfolds in two sections. The first introduces a classical model of the noble, but too-proud figure who assumes knowledge and authority that he does not possess - namely, John Milton's protagonist in the epic poem Paradise Lost. Satan's heroism, strength, and striving are misguided pride; similarly, pedagogical hybris - or, arrogance in instruction - is educational idealism stripped of its romanticism. The second section of this essay abandons references to Milton's text, but establishes, via analogy, a connection between Milton's Satan and contemporary pedagogues in order to contextualize the notion of modesty within educational discourse. 
It may appear at the outset that this essay undermines its core position by professing knowledge about appropriate approaches to pedagogy, even as it argues for 'modesty' and for 'ignorance'. Yet, this paper is intended to be grist for the hermeneuticists' mill - in other words, a discussion piece. Acknowledged ignorance ${ }^{1}$ is not the product of psychological or intelligence testing, nor does it follow from the careful examination of the literature dissecting 'best' educational practices; it is, despite its seeming haughtiness, a humble and modest approach to pedagogy.

We educationists are always ignorant. Not because knowledge is unknowable (in the relativistic or postmodern sense), but because our pedagogical knowledge can never be complete. The dialogic or hermeneutic processes by which we build deeper and richer understandings cease when we claim any form of definitive or final knowledge. The conception of ignorance for which this essay argues has a positive connotation, for it is a necessary pre-condition to continue questioning, falsifying, testing, and researching. Knowledge claims that are posited as complete satisfy agents seeking 'what works' in education, but they are ignorant (with a negative connotation) because they proudly profess to understand phenomena of which they see only a narrow part.

\section{Milton's Satan - Hybris and False Knowledge}

In Paradise Lost, John Milton sets up Satan as the conventional hero-type in order to show that (at least by Christian standards) the classical protagonist is merely a forlorn luminary. The poetic passages that describe Satan reflect the character's internalized struggle between good and evil. The verse mixes admiration and debasement of Satan and thus mirrors the manner in which the character's heroism is undermined by pride and misguided aims. Satan's excessive pride — or, hybris — is the fountainhead of his downfall. Milton's message bears pedagogical implications. Educators, enthroned at the forefront of the classroom and seated upon cushioned chairs before broad and imposing desks, should be reflexive and humble pedagogues.

The temptation to classify Satan as a hero dwindles as layers of the poem's lyric beauty are stripped away. Milton does not deny the character's grandeur but, like an eclipsed sun, Satan's goodness and godliness are veiled by glory and pride:

\section{He above the rest \\ In shape and gesture proudly eminent \\ Stood like a tower; his form had yet not lost \\ All her original brightness, nor appeared \\ Less than archangel ruined, and the excess \\ Of glory obscured. ${ }^{2}$}

The weighty image of an eclipse bears further unraveling. The sun is analogous here to the divine, to majesty, to wisdom and to truth. Satan's potential to attain these ideas is eclipsed by his unrelenting pretensions and pride.

At first glance, Satan's ambition and drive are not necessarily or entirely 
contemptible. In the first four books of Paradise Lost, Satan is the typical hero of classical epic. Milton stresses his stature, his courage in the face of adversity and his cunning. Satan is given a position of authority, yet the poet's words implicitly point to the character's paradoxical duality. "Satan exalted sat, by merit rais'd, / To that bad eminence." ${ }^{3}$ Bad eminence is an oxymoronic induction of the character's spiritual schism, while "exaltation" presumes haughtiness.

The devil is passionate and inspirational but, even after being exiled from heaven, he stubbornly insists on carrying on a futile war. His oft-celebrated address to Beelzebub is often deemed a demonstration of defiance, but it is dripping with resolute unwillingness to humbly resign claims to knowledge or power: "What though the field be lost? / All is not lost." ${ }^{4}$

Satan is undone by his hybris. This term, usually understood as the protagonist's "fatal flaw", is better translated as "sin" or "blasphemy." It leads to his literal and figurative fall from grace. Like Homer's Achilles and Sophocles' Oedipus, Milton's Satan plummets to despair and desolation as a direct result of arrogance and pride: "And with hope farewell fear, / Farewell remorse: all good to me is lost; / Evil be thou my good." 5 There are, too, pedagogical falls from grace.

Book IV is the breaking point for Satan for, here, he shows incredible consciousness and internal conflict. When accosting the sun, for example, he reveals guilt, remorse, and awareness of the fact that excessive pride and ambition cost him his place in Heaven. He considers repenting but his pride overcomes his humility: "Disdain forbids ... and (my) dread of shame." 6

Throughout the poem, Milton's language hints at the duality that is so candidly expressed in Book IV. Satan is not heroic because his approach to knowledge lacks an essential quality: modesty. His proud struggle for knowledge and power, ironically, enslaves him in the isolation of his un-whole (and unholy) knowledge and pride. Similarly, the classical protagonists, whose characters embody the duality of heroism and hybris, cannot be deemed "heroic" in Miltonic terms.

Satan sets out alone on a voyage of the vast abyss in search of Paradise. Like an intrepid explorer on the expansive sea, he challenges the circumscribed limitations of the cosmos:

\author{
So eagerly the fiend \\ O'er bog or steep, through strait, rough, dense, or rare, \\ With head, hands, wings, or feet pursues his way, \\ And swims or sinks, or wades, or creeps, or fyyes.?
}

Satan, here, resembles Homer's heroic figure, Odysseus, struggling against the angry seas in search of an Ithaca. Although the passage attaches heroic significance to Satan's travel, the paradoxical quality of "the fiend's" heroism is apparent. He not only "swims" and "flyes", he also "sinks" and "creeps." Here is a failed and faltering nobility. Satan's determination is undaunted. His modesty is absent. He will not query or question his assumptions. His knowledge and authority are debased and incomplete. 
Milton shows that the typical classical hero figure, like Satan, has an extraordinary appeal on the surface level. In Book IX, the image of the possessed serpent embodies this thought with stark clarity. Although the very notion of Satan (inside a slithering and sneaky snake), provoking humankind's "Fall" is appalling, the poet paints a magnificent image:

\section{His Head \\ Crested aloft, and Carbuncle his Eyes; \\ With burnisht Neck of verdant Gold, erect \\ Amidst his circling Spires, that on the grass \\ Floted redundant; pleasing was his shape, \\ And lovely, never since of Serpent kind \\ Lovelier.}

Satan's neck glimmers like gold, which is like the devil, in essence, nothing more than a polished, idolized diversion. All that glitters is not gold and, similarly, all that is admirable is not necessarily heroic. Or, in academic terms, all that is measurable, testable, quantifiable, publishable, and seed for promotion or funding grants is not necessarily noble, just, wise, or emancipating.

\section{Acknowledging Ignorance - The Pedagogical Implications of Satan's Fall}

Pedagogical reflexivity, when promoted and practiced, can further understanding, acceptance, and empathy for others. The others, insofar as educators are concerned, include students, colleagues, parents, and administration. In order to achieve selfunderstanding and empathetic understanding for alternative experiences, it is important to wage war against hybris - excessive pride. The keystone here is the term 'excessive'. Pride in self, community, nation, and interests is a constructive corollary to self-worth and-motivation. Excessive pride - arrogant self-righteousness - is destructive.

Hybris, then, is the enemy. It represents, in a Socratic sense, the greatest form of ignorance - pretending or assuming to know that which is not known. From the time of classical Athens to the present day, it has been regarded as the root of evil, of vice, and of crime no less than of intellectual futility and of error. From the point of view of the pedagogical community, the battle against ignorance seems to be a comparatively simple affair, waged within the walls of the educational superstructure. With a good system of schools, it could theoretically be possible, within a generation or two, to increase knowledge, decrease crime, give rise to hope, and quell despair.

Such is the naive optimism of some hypothetical citizen who has listened, perhaps, too readily to commencement addresses, justifications of educational expenditures, and other outpourings of the prophets of education. For this person, democracy, modern civilization, everything that makes life seem worth living, rests upon education, upon the work of the schools, substituting knowledge for ignorance. However, 
from the standpoint of the teacher in service, the matter is not so simple. The educator, in relation to the child, is often conceived as the knower. The child, subservient, requiring knowledge and experience, is conceived as ignorant. The image is akin to that associated with the ignorance/innocence of the newborn child, whose experiences are, in relative measure, small. It is important, we might think, that such ignorance should not persist, but should be exchanged for knowledge as imperiously as may be; and in principle, it looks as though, with adequate equipment and instruction, the thing could be done.

Yet, the educator, particularly when confronted with a group of children - a cohort of the 'unknowing' - actually bears the onus of learning. The teacher must learn how to teach. In practice, the child's ignorance is exchanged for whatever beliefs the adults who surround him think fit to inculcate. The complexities of teaching one child is projected exponentially into the realm of the difficult when considered in terms of a classroom, of a school, of a school board, or of a province. In having to face these complexities, it is the educator who is ignorant.

The child (as Rousseau and Dewey, for starters, repeatedly pointed out), on entering school, is not a receptive waxen tablet, all ready for the teachers to write upon and to fill with understanding. His mind is not a sheet of white paper devoid of all characters. The home, the street, and the community have already set their stamp firmly upon it. These factors all complicate immensely the situation for the educational system.

From the educational structure's perspective, then, the child is only to a slight extent educable by the teacher. The optimistic hopes of every common citizen, that the teachers will do the whole work of the community, fade into the remote distance. If the educational system is to wage war against hybris, it is necessary to analyze and discover clearly the nature, the numbers, and the power of the enemy.

The chief value of 'Socratic' ignorance is that, when recognized humbly, it acts as a stimulus, awakening the reflective powers of the self to fuller exercise. To know, as Socrates might have said, that we do not know, and to know that the deficiency is to be remedied by a fuller understanding of the nature and function of the knowing self, is the first step toward the reflective self-development and growth in spiritual insight which are integral to the health of any society. Self-knowledge is central to developing richer conceptions of the broader community or nation. It vitalizes the otherwise narrow and one-sided satisfaction in the impersonal tabulation of objective statistics. Without any inner significance, without individual and personal meanings, facts are effectively meaningless. When we pretend that the entire cosmos is knowable and discernable by statistical and scientific analysis, we blindly propagate and systematize egotism and ignorance.

The humble recognition of our own ignorance is the beginning of wisdom. Why should there be a unity in the world-picture constructed by scientists and empiricists? The unity belongs, not to the objective elements considered, but to the knowing mind. Educators should unify phenomena, or, rather, try to unify them. Their attempts are only partly successful, and unity remains an ideal, a transcendental demand rather than an empirically accomplished fact. They project their own selves, 
with their demands for unity, hither and thither in every direction in which they look for knowledge. Educational modesty entails realizing and acknowledging the limited scope of our understanding, whether experientially- or experimentally-derived. Quests for claims on ultimate or definitive answers, in other words, end questions. Pedagogically, Socratic ignorance - recognition that we do not completely know, that we never shall, but that there is value in trying - orients us to inquire and not to answer.

This is wisdom. This respects the limitations of knowledge. Milton's Satan ignored all limitations; he overstepped. His downfall is tragic because it was avoidable. Heroism is the flip-side of folly. Pedagogical assumptions that are unchallenged and unwarranted, similarly, are monuments to ignorance. In an educational context, the implication is that knowledge must be limited, contingent, and elusive. It is personal, flimsy, and subject to change or evolution. Educators, consequently, cannot ever know. They must always learn. This is essential to the construction of reflexive practice leading to personal and professional self-understanding and -acceptance.

In summation, I return to the notion of a pedagogical vision that I would like to offer to educators and administrators. We live in a world of ideas, rather than of facts. These ideas are elusive and mutable. They need be approached humbly. Arrogance in pedagogical orientation is dangerous. It limits reflexivity. Educators, who assume to know and venture to teach, do so blindly. Our prior assumptions, unchecked, blind us. Pedagogically, the consequences can be perilous.

\section{Conclusion}

The arguments made here and above are not original. The references to centuries-old statements should make that point evident. It might appear passé to deal in 'classics', but there is no pedantry or shame intended in this (re)presentation of ideas (even if these are attributed to dead, European, white, men). Despite constant reference to the Latin root of education being 'educare' — drawing out_- pedagogues are still problematized by the putting in of knowledge. In Paolo Freire's terms ${ }^{9}$, how can an educator best deposit, knowledge into a learner's account of understanding?

Socrates, millennia earlier, provided a metaphor for pedagogy that posited the educator in a position of modesty and reciprocity towards the learner. The pedagogue is, in accordance with this educational perspective, a midwife. Teaching and learning are akin to birthing — the drawing out, in other words — of knowledge. ${ }^{10}$ The educator neither creates the child nor deposits it in the expectant mother. The pedagoguemidwife facilitates, prompts, encourages, reflects, and responds. Any forceful pulling or withdrawing, in birth, as in learning, is violent and cruel. We, pedagogues and educationists, who stake our careers on 'knowing', need be cautious to avoid the falls of excessive pride; our claims to specialized 'knowledge' might be little more than immodestly-veiled hybris. 


\section{Notes}

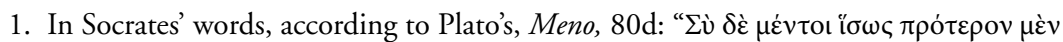

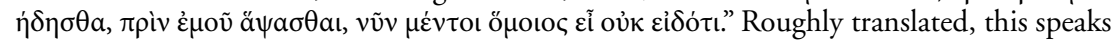
quite directly to this paper's thesis: "You might have known some thing before you came into contact with me; but now, like me, you acknowledge your ignorance" (my translation).

2. John Milton, Paradise Lost (Cambridge: Cambridge University Press, 1972), I: 589-94.

3. Ibid., II: 5-6.

4. Ibid., I: 105-7.

5. Ibid., IV: 108-13.

6. Ibid., IV: 82.

7. Ibid., II: $947-50$.

8. Ibid., IX: 499-505.

9. See, for example, Pedagogy of the Oppressed. Freire's 'banking' metaphor for knowledge, wherein the learned teacher deposits learning into the ignorant student's mind, is apropos here.

10. In Plato's Meno, Socrates demonstrates how a slave boy, without any prior or formal schooling, understands the Pythagorean Theorem. Socrates' responsive and careful questioning 'draws out' this understanding, rather than inculcating it in the learner. 